\title{
PENGEMBANGAN BUKU AJAR METODE NUMERIK BERBASIS KONSTRUKTIVISME DI IAIN BATUSANGKAR
}

\author{
Christina Khaidir \\ Jurusan Tadris Matematika, Fakultas Tarbiyah dan Ilmu Keguruan IAIN Batusangkar \\ Korespondensi: Jln. Sudirman No. 137 Kubu Rajo Lima Kaum Batusangkar.
}

\begin{abstract}
The purpose of this research is to develop textbook materials on constructivismbased numeric method. This idea is based on the reality found the field that some textbook materials on that issue are not relevant anymore. This research used research and development using Plom model. The stages consist of front-endanalysis, prototype, and assessment. Data were validated using experts' and practical validation. The textbook was validated by experts who were competence in their academic field. Based on the experts' validation result, the textbook was deemed valid. In terms of practicality, the textbook was also considered practical.
\end{abstract}

Kata Kunci: Buku Ajar Metode Numerik, Pendekatan Konstruktivisme

\section{PENDAHULUAN}

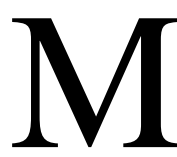

ata kuliah Metode Numerik diberikan di Jurusan Tarbiyah Program Studi Tadris Matematika STAIN Batusangkar dengan tujuan untuk mempersiapkan atau membekali mahasiswa tentang konsep dasar dan teknik menggunakan metode numerik dalam menyelesaikan persoalan-persoalan matematis, dimana penyelesaian secara analitis tidak dapat digunakan. Metode numerik merupakan teknik-teknik yang digunakan untuk menyelesaikan masalah matematika melalui operasi hitungan yang terdiri dari operasi tambah, kurang, kali, dan bagi (Susila, 1993: 1). Ciri khas metode numerik adalah mencakup sejumlah besar perhitungan yang tidak terlepas dari pemakaian alat bantu hitung seperti kalkulator dan komputer.

Kesulitan dalam memahami konsep dan algoritma penyelesaian metode numerik mengakibatkan mahasiswa menghabiskan waktu cukup banyak untuk bisa menguasai materi dengan baik. Penggunaan komputer untuk mempermudah proses perhitungan tidak terlaksana sebagaimana mestinya karena mahasiswa juga tidak menguasai dengan baik dasar-dasar pemograman komputer.

Buku sumber yang dijadikan referensi pada mata kuliah Metode Numerik di Jurusan tarbiyah Program Studi Tadris Matematika sudah sesuai dengan silabus perkuliahan, tetapi buku tersebut cukup sulit dipahami dari segi bahasa untuk lingkup mahasiswa dengan kualitas input beragam. Logika berbahasa yang digunakan membutuhkan analisis dan penguasaan matematika yang cukup tinggi untuk memahaminya. Beberapa istilah yang digunakan tidak umum dikenal di lingkungan mahasiswa. Ada beberapa materi yang dianggap penting dalam buku tersebut disajikan dengan kajian matematis yang tidak relevan dengan pengetahuan dasar matematis mahasiswa.

Berdasarkan permasalahan yang telah dikemukakan di atas, dibutuhkan 
buku ajar Metode Numerik yang berbasis pendekatan konstruktivisme. Buku ajar tersebut memuat pertanyaan-pertanyaan elaborasi atau masalah sebagai titik tolak kegiatan konstruksi pengetahuan mahasiswa. Buku tersebut juga menggunakan bahasa yang mudah dipahami dari segi logika bahasa matematika serta menggunakan istilah yang umum digunakan di lingkungan mahasiswa. Penyajian isi buku juga relevan dengan kemampuan mahasiswa Jurusan Tarbiyah Program Studi Tadris Matematika. Oleh karena itu, penulis tertarik untuk mengadakan penelitian tentang pengembangan buku ajar berbasis konstruktivisme. Untuk itu dilakukan penelitian dengan judul "Pengembangan Buku Ajar Metode Numerik Berbasis Konstruktivisme di STAIN Batu sangkar".

\section{Rumusan Masalah}

Berdasarkan latar belakang masalah di atas, masalah dalam penelitian ini dapat dirumuskan sebagai berikut:

1. Bagaimanakah validitas dari buku ajar Metode Numerik berbasis konstruktivisme di STAIN Batusangkar?

2. Bagaimanakah praktikalitas dari buku ajar Metode Numerik berbasis konstruktivisme di STAIN Batusangkar?

\section{Tujuan Penelitian}

Tujuan umum penelitian ini adalah untuk menghasilkan buku ajar Metode Numerik berbasis konstruktivisme di STAIN Batusangkar. Sedangkan tujuan khususnya adalah:

1. Untuk menentukan validitas dari buku ajar Metode Numerik berbasis konstruktivisme di STAIN Batusangkar.

2. Untuk mengetahui praktikalitas dari buku ajar Metode Numerik berbasis konstruktivisme di STAIN Batu sangkar.

\section{KAJIAN PUSTAKA}

\section{Landasan Teori}

\section{Buku Ajar}

Buku ajar adalah bahan ajar yang dirancang dengan baik sesuai dengan prinsip-prinsip instruksional untuk mencapai tujuan pembelajaran suatu mata kuliah. Bahan ajar adalah bahan-bahan atau materi perkuliahan yang disusun secara sistematis yang digunakan dosen dan mahasiswa dalam perkuliahan (Pannen dan Purwanto, 2005: 6). Bahan ajar bersifat mandiri, artinya dapat dipelajari oleh mahasiswa secara mandiri karena bahan ajar tersebut mempunyai struktur dan urutan yang sistematis, yaitu:

a. Menjelaskan tujuan instruksional yang akan dicapai,

b. Memotivasi mahasiswa untuk belajar,

c. Mengakomodasikan kesukaran belajar mahasiswa,

d. Memberikan kesempatan latihan bagi mahasiswa,

e. Menyediakan rangkuman,

f. Berorientasi pada mahasiswa secara individual (learner oriented).

Sebuah buku ajar dapat mencakup antara lain petunjuk belajar, kompetensi yang akan dicapai, informasi pendukung, latihan-latihan, petunjuk kerja dapat berupa lembar kerja, dan evaluasi (Majid, 2008: 174). Dengan demikian dapat disarikan bahwa buku sebagai bahan ajar merupakan seperangkat materi yang disusun secara sistematis sehingga tercipta suasana atau lingkungan yang memungkinkan mahasiswa belajar dengan baik. Struktur buku ajar ini berisikan kompetensi yang akan dicapai, petunjuk belajar, informasi pendukung, latihanlatihan, dan rangkuman.

\section{Perkuliahan Metode Numerik}

Mata kuliah Metode Numerik adalah mata kuliah yang mengkaji berbagai metode alternatif yang ada dalam upaya menyelesaikan persoalan- 
persoalan matematis yang tidak mungkin diselesaikan secara analitik. Metode artinya cara, nemerik artinya angka. Jadi secara harfiah, metode numerik berarti cara berhitung dengan menggunakan angka-angka. Menurut Munir (2010: 5) metode numerik adalah teknik yang digunakan untuk memformulasikan persoalan matematik sehingga dapat dipecahkan dengan operasi perhitungan/aritmatika biasa (tambah, kurang, kali dan bagi).

2. Pendekatan Pembelajaran Konstruktivisme

Menurut Rusman (2010: 193) konstruktivisme merupakan landasan berpikir dalam pembelajaran kontektual, yaitu bahwa pengetahuan dibangun oleh manusia sedikit demi sedikit yang hasilnya diperluas melalui konteks yang terbatas. Esensi dari konstruktivisme adalah ide bahwa peserta didik menemukan dan mentransformasikan suatu informasi yang kompleks ke situasi lain dan jika dikehendaki informasi tersebut akan menjadi milik mereka sendiri.

Penerapan filosofi konstruktivisme dalam pembelajaran menurut Nurhadi dkk (2004: 39) dapat dilakukan dalam lima langkah yaitu:

a. Pengaktifan pengetahuan yang sudah ada (activating knowledge). Struktur pengetahuan awal yang sudah dimilki mahasiswa perlu dibangkitkan sebelum diberikan informasi yang baru.

b. Pemerolehan pengetahuan baru (acquiring knowledge) dilakukan dengan cara mempelajari secara keseluruhan terlebih dahulu, kemudian baru memperhatikan detailnya.

c. Pemahaman pengetahuan (understanding knowledge) dapat dilakukan melalui penyusunan konsep atau ide sementara oleh mahasiswa, melakukan sharing dengan orang lain untuk memperoleh tanggapan, kemudian merevisi dan mengembangkan konsep atau ide-ide tadi berdasarkan tanggapan yang diperoleh.

d. Menerapkan pengetahuan dan pengalaman yang diperoleh (applying knowledge) dapat dilakukan melalui pemecahan masalah.

e. Melakukan refleksi (reflecting on knowledge) untuk dapat mendekontekstualkan pengetahuan agar pembaca memahami seutuhnya dan dapat diterapkan secara luas.

3. Buku Ajar Berbasis Pendekatan Konstruktivisme

Buku ajar Metode Numerik berbasis konstruktivisme yang dikembangkan menggunakan pendekatan filosofi konstruktivisme dalam lima langkah sebagaimana yang dikemukakan oleh Nurhadi (2004: 39) yaitu:

a. Pengaktifan pengetahuan yang sudah ada

Pengaktifan pengetahuan yang sudah ada dimunculkan melalui pertanyaanpertanyaan elaborasi yang disajikan dalam buku ajar. Pertanyaan-pertanyaan yang diajukan menggiring pembaca untuk mengingat kembali pengetahuan yang sudah ada sebelumnya dan membuat hubungan dengan informasi baru yang terdapat dalam buku ajar.

b. Pemerolehan pengetahuan baru

Gambaran umum, relevansi materi, dan kompetensi pendukung menyajikan pengetahuan tentang materi secara umum. Pembaca sudah diberikan pengetahuan baru secara umum di awal setiap bab. Pengetahuan baru secara lengkap diperoleh pembaca dari materi yang disajikan secara detail pada bagian isi setiap bab.

c. Pemahaman pengetahuan

Penyajian materi dalam bentuk pertanyaan-pertanyaan disertai dengan gambar-gambar yang mendukung dalam buku ajar memfasilitasi aktivitas diskusi mahasiswa. Pemahaman pengetahuan 
oleh pembaca juga dapat dilakukan melalui contoh-contoh soal. Buku ajar ini memfasilitasi mahasiswa untuk melakukan diskusi melalui penyajian materi dan contoh-contoh soal.

d. Menerapkan pengetahuan dan pengalaman yang diperoleh

Penyajian beberapa permasalahan melalui latihan, dan latihan ulangan dalam buku ajar dapat memperluas pengetahuan dan pengalaman mahasiswa. Mahasiswa dapat menerapkan pengetahuan dan pengalaman yang diperoleh dengan menyelesaikan latihanlatihan yang diberikan.

e. Melakukan refleksi

Refleksi dilakukan untuk mendekontekstualkan pengetahuan sehingga bisa dipahami secara utuh dan dapat diterapkan secara luas. Dekontekstualisasi muncul karena adanya perbedaan situasi yang dialami pembaca dengan situasi yang terdapat dalam teks bacaan.

\section{METODE PENELITIAN}

\section{Jenis Penelitian}

Sesuai dengan permasalahan yang akan diteliti, maka metode penelitian yang digunakan adalah metode penelitian pengembangan (development research). Menurut Akker dan Plomp (1994: 462) tujuan penelitian pengembangan adalah:

1. Better understanding of the implementation problems of the teachers;

2. Development of prototypical project interventions (training, materials, support), including empirical evidence of their quality;

3. Generating methodological directions for the design and evaluation of such products or intervention;

4. Increased (both individual and collective) expertise of the various participant.

Penelitian ini dilaksanakan sesuai dengan tujuan penelitian di atas yaitu development of prototypical project interventions. Dalam hal ini penelitian pengembangan digunakan untuk mengembangkan buku ajar berbasis konstruktivisme yang valid dan praktikal untuk mahasiswa di perkuliahan Metode Numerik.

\section{Rancangan Penelitian dan Prosedur Penelitia}

Menurut Van Den Akker dalam Ahmad Fauzan (2002: 62), rancangan penelitian pengembangan ini terdiri tiga tahap yaitu:

1. Analisis muka-belakang (front-end analysis).

2. Tahap prototipe (prototype).

3. Tahap penilaian (assessment).

Namun pada penelitian ini hanya digunakan dua rancangan yaitu analisis muka-belakang (front and analysis) dan tahap prototype. Berikut ini uraian prosedur penelitian:

1. Tahap analisis muka-belakang (front and analysis)

Pada tahap ini dilakukan identifikasi masalah dan kebutuhan dalam pelaksanaan perkuliahan metode numerik di Jurusan Tarbiyah Program Studi Tadris Matematika terutama yang terkait dengan pendekatan konstruktivisme. Pengumpulan data dilakukan melalui wawancara dengan tim dosen pembina mata kuliah metode numerik, pengumpulan dokumen silabus per-kuliahan, dan buku-buku teks metode numerik.

1. Tahap Prototipe (prototype)

Setelah dilakukan analisis mukabelakang, maka hasilnya digunakan untuk merancang prototipe buku ajar berbasis konstruktivisme pada mata kuliah metode numerik.

2. Tahap Penilaian (assessment)

Setelah prototipe selesai dirancang, dikonsultasikan apakah sudah layak untuk divalidasi atau belum, jika belum 
diperbaiki sampai layak. Berikut uraian masing-masing tahap:

a. Tahap validasi

Ada dua macam validasi yang digunakan pada buku ajar, yaitu:

1) Validitas isi yaitu apakah buku ajar berbasis konstruktivisme yang telah dirancang sesuai dengan silabus mata kuliah.
2) Validitas konstruk yaitu kesesuaian komponen-komponen buku ajar dengan indikator-indikator yang telah ditetapkan.

Adapun aspek-aspek yang divalidasi dapat dilihat dari table 1 berikut.

Table 1. Aspek-aspek Validitas Buku Ajar

\begin{tabular}{llc}
\hline \multicolumn{1}{c}{ Aspek yang Diamati } & $\begin{array}{c}\text { Metode Pengumpulan } \\
\text { Data }\end{array}$ & Instrument \\
\cline { 1 - 1 } A. Kelayakan isi & Angket & Lembar validasi \\
\cline { 1 - 1 } B. Penyajian & & \\
\cline { 1 - 1 } C. Kebahasaan & & \\
\hline D. Kegrafikan & & \\
\hline
\end{tabular}

b. Tahap praktikalitas

Pada tahap ini diujicobakan terbatas dirancang oleh dosen dan mahasiswa di di satu kelas yaitu kelas A. Uji coba dilakukan untuk melihat praktikalitas kelas. Adapun komponen yang akan atau keterpakaian buku ajar yang sudah diteliti dapat dilihat pada tabel 2 berikut.

Tabel 2. Aspek-aspek Praktikalitas Buku Ajar

\begin{tabular}{llll}
\hline No & \multicolumn{1}{c}{ Aspek } & \multicolumn{1}{c}{$\begin{array}{c}\text { Metode } \\
\text { Pengumpulan Data }\end{array}$} & Instrument \\
\hline 1. & $\begin{array}{l}\text { Kemudahan dalam } \\
\text { penggunaan buku ajar metode } \\
\text { numerik berbasis } \\
\text { konstruktivisme untuk } \\
\text { meningkatkan pemahaman } \\
\text { mahasiswa. }\end{array}$ & Angket respon & $\begin{array}{l}\text { Angket } \\
\text { praktikalitas }\end{array}$ \\
\hline
\end{tabular}

\section{Subjek Penelitian}

Mahasiswa yang dijadikan subjek dalam penelitian ini adalah mahasiswa kelas A Jurusan Tarbiyah Program Studi tadris Matematika STAIN Batusangkar yang mengambil mata kuliah metode numerik pada semester genap tahun akademik 2014/2015. Mahasiswa yang menjadi subjek penelitian berjumlah 10 orang.

\section{Teknik Pengumpulan Data dan Instrumen Penelitian}

Teknik pengumpulan data untuk menentukan validitas buku ajar berbasis konstruktivisme pada mata kuliah metode numerik dan instrument yang digunakan dalam penelitian ini adalah angket. Tekinik pengumpulan data untuk mengetahui praktikalitas buku ajar berbasis konstruktivisme pada mata kuliah metode numerik adalah menggunakan angket respon. 
Instrumen yang digunakan dalam pengembangan ini adalah sebagai berikut.

\section{Lembar Validasi}

Lembar validasi digunakan untuk mengetahui apakah buku ajar berbasis konstruktivisme dan instrument yang telah dirancang valid atau tidak. Lembar validasi pada buku ajar berbasis konstruktivisme berisi aspek-aspek yang telah dirumuskan pada Tabel 1 di atas. Masing-masing aspek dikembangkan menjadi beberapa pernyataan.

\section{Angket}

Angket digunakan untuk mengetahui praktikalitas penggunaan buku ajar berbasis konstruktivisme setelah perkuliahan metode numerik oleh mahasiswa. Angket yang digunakan adalah angket tertutup yang berisi pertanyataanpernyataan mengenai petunjuk, isi dan bahasa. Pengisian angket menggunakan skala Likert dengan range 1 sampai 4 . Sebelum angket ini digunakan, terlebih dahulu dilakukan validasi instrument. Validasi bertujuan untuk memperoleh angket praktikalitas yang valid dan dapat digunakan untuk mengukur praktikalitas buku ajar yang dikembangkan. Aspek penilaian terdiri dari format angket, bahasa yang digunakan dan butir pernyataan angket

\section{Teknik Analisa Data}

Teknik analisis data validitas, praktikalitas yang diperoleh melalui instrumen yang telah dikemukakan di atas dijelaskan sebagai berikut.

Validasi

Hasil tabulasi tiap tagihan dicari persentasenya dengan rumus:

Berdasarkan hasil persentase, setiap tagihan dikategorikan pada:

$$
\text { Persentas }=\frac{\sum \text { skor peritem }}{\text { skor maksimum }} \times 100 \%
$$

Tabel 4. Kategori Vasliditas Instrumen dan Buku Ajar

\begin{tabular}{cc}
\hline$(\%)$ & Kategori \\
\hline $0-20$ & Tidak valid \\
$21-40$ & Kurang valid \\
$41-60$ & Cukup valid \\
$61-80$ & Valid \\
$81-100$ & Sangat valid \\
\hline
\end{tabular}

(Modifikasi dari Riduwan: 2005: 89)

Angket

Data hasil tanggapan peserta didik melalui angket yang terkumpul, kemudian ditabulasi. Hasil tabulasi tiap tagihan dicari persentasenya dengan rumus:

$$
\text { Persentase }=\frac{\sum \text { skor peritem }}{\text { skor maksimum }} \times 100 \%
$$

Berdasarkan hasil persentase, setiap tagihan dikategorikan pada: 
Tabel 5. Kategori Praktikalitas Instrumen dan Buku Ajar

\begin{tabular}{cc}
\hline$(\%)$ & Kategori \\
\hline $0-20$ & Tidak praktis \\
$21-40$ & Kurang praktis \\
$41-60$ & Cukup praktis \\
$61-80$ & Praktis \\
$81-100$ & Sangat praktis \\
\hline
\end{tabular}

(Modifikasi dari Riduwan: 2005: 89)

\section{HASIL PENELITIAN DAN PEM- BAHASAN}

\section{Hasil Analisis Muka-Belakang (Font- End Analisys)}

Prototipe buku ajar berbasis konstruktivisme pada mata kuliah metode numerik dirancang berdasarkan hasil analisis muka belakang. Kegiatan ini dimulai dari melakukan wawancara dengan dosen metode numerik STAIN Batusangkar. Berdasarkan hasil wawancara diperoleh informasi mengenai keterbatasan buku ajar metode numerik yang mudah dipahami mahasiswa. Beberapa materi dalam buku ajar sudah diberikan pada mata kuliah dasar yang merupakan prasyarat untuk mengambil mata kuliah metode numerik. Dosen juga belum pernah menulis buku ajar metode numerik.

Analisis silabus dilakukan untuk melihat kesesuaian antara materi ajar dengan kompetensi yang harus dicapai mahasiswa. Kompetensi utama mata kuliah metode numerik adalah mahasiswa dapat menjelaskan konsep galat, dapat menggunakan metode numerik untuk menentukan akar persamaan tak linier, menyelesaikan sistem persamaan linier, menginterpolasi titik-titik data, dan dapat menyelesaikan persoalanpersoalan yang terkait dengan metode numerik. Silabus mata kuliah Metode Numerik dapat dilihat pada Lampiran 9.

Hasil analisis silabus antara lain adalah materi yang disajikan dalam silabus sudah sesuai dengan komputasi yang harus dicapai mahasiswa. Urutan materi juga sudah cocok karena materi sistem bilangan dan galat merupakan materi dasar sebelum mempelajari materi selanjutnya. Materi Akar Persamaan Tak Linier, Sistem Persamaan Linier, dan Interpolasi tidak saling terkait. Untuk memahami materi Sistem Persamaan Linier tidak memerlukan pemahaman terhadap Akar Persamaan Tak Linier. Oleh karena itu, penempatan ketiga materi tersebut disesuaikan saja dengan urutan pada buku ajar yang ada.

Berdasarkan analisis silabus juga diketahui bahwa beberapa subpokok bahasan materi Sistem Persamaan Linier sama dengan subpokok bahasan pada mata kuliah Aljabar Linier Elementer. Materi eliminasi Gauss, Eliminasi Gauss-Jordan, dan pembalikan (Inverse) Matriks juga dipelajari pada mata kuliah Aljabar Linier Elementer yang merupakan mata kuliah prasyarat untuk Metode Numerik.

Materi yang ada pada buku tersebut sudah mencakup sebagian besar kompetensi yang harus dicapai mahasiswa. Akan tetapi, buku tersebut cukup sulit dipahami dari segi bahasa untuk lingkup mahasiswa STAIN Batusangkar dengan kualitas input rata-rata menengah ke bawah. Salah satu materi yang sulit dipahami oleh mahasiswa adalah materi kekonvergenan pada metode iterasi titik tetap. Teorema yang digunakan menggunakan analisis matematika yang cukup 
tinggi untuk mahasiswa STAIN Batusangkar.

Mahasiswa juga sering keliru dalam memahami konsep $\left|\frac{a_{k}}{a_{n}}\right|$ pada materi Lokalisasi Akar. Sebagai contoh, dalam menghitung $r$ pada persamaan polinom $p(x)=x^{5}-3 x^{3}+x^{2}-1$. Mahasiswa sering menuliskan seperti berikut:

$\mathrm{r}=1+\operatorname{maks}_{1 \leq \mathrm{k} \leq 5}\left|\frac{1}{1}, \frac{-3}{1}, \frac{1}{1}\right|=1+$ $\operatorname{maks}_{1 \leq k \leq 5}|1,-3,1|=1+1=2$

Mahasiswa memilih nilai yang maksimum tanpa memperhatikan tanda mutlaknya sehingga keliru dalam mendapatkan nilai r. Mahasiswa baru mengerti setelah melihat jawaban yang disajikan pada buku tersebut. Akan tetapi, kekeliruan tersebut biasanya berulang kembali pada saat mahasiswa mengerjakan soal dengan fungsi yang berbeda.

Buku Metode Numerik terbitan Penerbit Informatika tahun 2010 yang ditulis oleh Rinaldi Munir merupakan buku kedua yang dianalisis. Buku ini sangat bagus dalam penyajian materi, akan tetapi buku tersebut banyak menggunakan istilah-istilah komputasi dan pemprograman. Hal ini dikarenakan buku tersebut diperuntukkan sebagai buku ajar untuk mahasiswa teknik informatika. Contoh-contoh yang disajikan merupakan hasil komputasi dari bahasa pemprograman tertentu sehingga mahasiswa STAIN Batusangkar yang rata-rata tidak menguasai bahasa pemprograman sulit memahaminya.

Berdasarkan hasil analisis terhadap beberapa buku teks metode numerik di atas, buku ajar metode numerik yang dikembangkan berbasis konstruktivisme untuk memfasilitasi proses konstruksi pengetahuan oleh mahasiswa secara mandiri. Bahasa dan istilah yang di- gunakan mudah dipahami dan sudah umum dikenal di lingkungan STAIN Batusangkar. Buku ini juga mengupayakan penyajian dan penjelasan yang logis untuk setiap perbedaan yang ditemukan pada buku-buku teks sebelumnya.

\section{Hasil Perancangan Prototipe (Prototype)}

Prototipe buku ajar metode numerik yang dirancang dan dikembangkan mengacu pada pendekatan konstruktivisme. Bagian-bagian buku ajar yang dikembangkan disajikan berikut ini.

\section{Penyajian Materi Berbasis Kons- truktivisme}

Penyajian materi pada setiap bab diawali dengan penjelasan gambaran umum, relevansi materi, dan kompetensi pendukung. Dilanjutkan dengan penyajian materi, latihan, rangkuman, dan latihan ulangan. Penerapan pendekatan konstruktivisme dalam buku ajar ini sesuai dengan pendapat Nurhadi (2004: 39) dilakukan dalam lima langkah sebagai berikut.

a. Pengaktifan Pengetahuan yang Sudah Ada

Materi Bab I dimulai dengan membahas "Mengapa Menggunakan Metode Numerik". Pendekatan kons-truktivisme pada buku ajar ini bertitik tolak dari tantangan masalah yang muncul dalam mempelajari metode numerik. Hal ini sesuai dengan pendapat Steffe dan kieren dalam Suherman (2003: 75) yang mengatakan bahwa aktivitas matematika dalam pendekatan konstruktivisme dapat dimunculkan melalui tantangan masalah yang bisa muncul dalam materi kurikulum kelas biasa. Tantangan masalah pada Bab I berupa persoalan-persoalan matematis yang biasa muncul dalam berbagai bidang terapan matematika seperti terlihat pada Gambar 2. 
Gambar 2 menyajikan beberapa persoalan matematis yang terlihat sederhana dan mudah. Akan tetapi, persoalan tersebut ternyata sangat sulit bahkan beberapa diantaranya tidak mungkin diselesaiakan secara analitik sehingga diperlukan pendekatan numerik untuk menyelesaiakannya.

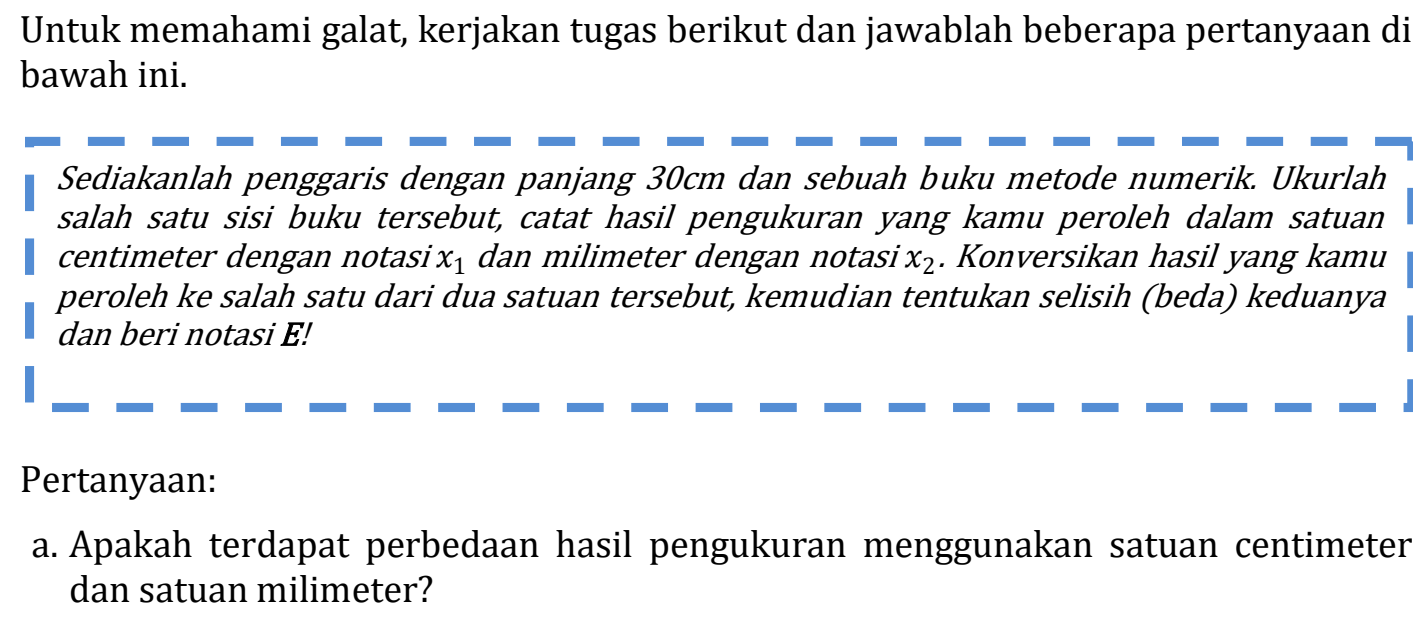

Pertanyaan:

a. Apakah terdapat perbedaan hasil pengukuran menggunakan satuan centimeter dan satuan milimeter?

\section{Gambar 2. Pengaktifan Pengetahuan yang Sudah Ada pada Bab I}

\section{b. Pemerolehan Pengetahuan baru}

Pengetahuan baru yang terkait dengan materi pada setiap bab bisa didapatkan pembaca melalui penyajian materi dengan pendekatan konstruktivisme. Pemerolehan pengetahuan baru pada Bab 2 disajikan melalui kegiatan pengukuran suatu benda untuk memahami konsep galat. Mahasiswa diminta melakukan kegiatan tersebut dan menjawab pertanyaan yang diberikan. Contoh pemerolehan pengetahuan baru dapat dilihat pada Gambar 3.

Sebagai contoh ilustrasi, tinjau sekumpulan persoalan matematik di bawah ini. Bagaimana cara anda menyelesaikannya?

1. Tentukan akar-akar persamaan polinom

$$
23,4 x^{7}-1,25 x^{6}+120 x^{4}+15 x^{3}-120 x^{2}-x+100=0
$$

2. Selesaikan sistem persamaaan linier:

$$
\begin{gathered}
1,2 a-3 b-12 c+12 d+4,8 e=18 \\
0,9 a+3 b-c+16 d+8 e=17 \\
4,6 a+3 b-6 c-2 d+4 e=19 \\
3,7 a-3 b+8 c-7 d+14 e=6 \\
2,2 a+3 b+17 c+6 d+12 e=9
\end{gathered}
$$

\section{Gambar 3. Pemerolehan Pengetahuan Baru Pada Bab 2}

\section{c. Pemahaman Pengetahuan}

Pemahaman pengetahuan dapat dilakukan melalui penyusunan ide sementara oleh mahasiswa, kemudian dilakukan sharing dengan orang lain, untuk kemudian disusun ide baru berdasarkan hasil sharing tersebut. Pemahaman pengetahuan dimunculkan dalam bentuk mahasiswa mengerjakan sesuatu dan menulis. Kegiatan yang diberikan dan pertanyaan-pertanyaan yang diajukan bertujuan untuk menumbuhkan pema- 
haman mahasiswa terhadap materi pelajaran. Mahasiswa dapat menyusun ide sementara mereka dengan melakukan kegiatan yang diminta, kemudian mereka dapat melakukan sharing sehingga diperoleh ide baru yang lebih tepat. Contoh pemahaman pengetahuan dapat dilihat pada Gambar 4.

Lakukanlah operasi penjumlahan, pengurangan, perkalian dan pembagian pada kedua bilangan tersebut dengan memperhatikan galat yang muncul pada setiap operasi!

a. Pada operasi penjumlahan, apakah yang terjadi dengan galat pada bilangan hasil penjumlahan $\hat{x}$ dan $\hat{y}$ ?

\section{Gambar 4. Pemahaman Pengetahuan pada Bab 2}

d. Menerapkan Pengetahuan dan kan melalui latihan dan latihan ulangan

Pengalaman yang Diperoleh

Kegiatan menerapkan pengetahuan dan pengalaman yang diperoleh dilakuyang terdapat pada setiap bab. Contoh latihan pada Bab 2 dapat dilihat pada Gambar 5.

\section{Latihan}

1. Bulatkan bilangan-bilangan berikut hingga 4 angka signifikan!
a. 48,21416;
b. 84,46235 ;
c. 0,0000171922435

2. Nyatakan bilangan-bilangan berikut dalam bentuk titik kambang dengan 4 angka signifikan!
a. 98,17;
b. $-100,988$;
c. 0,00047869 ;
d. $-13,800$

\section{Gambar 5. Latihan pada Bab 2}

\section{e. Melakukan Refleksi}

Setelah menyajikan masalah di atas, diberikan ulasan mengenai setiap persoalan tersebut. Ulasan yang diberikan berupa refleksi terhadap setiap persoalan untuk mendekontekstualkan pengetahuan awal mahasiswa. Ide yang dipikirkan oleh mahasiswa untuk memecahkan masalah tersebut dapat berubah sesuai dengan situasi yang terdapat pada persoalan di atas.
Kegiatan refleksi yang diberikan mengupayakan mahasiswa untuk berpikir apakah pengetahuan yang mereka miliki sudah cukup untuk menjawab permasalahan tersebut. Proses konstruksi pengetahuan mahasiswa terus diarahkan hingga terjadi perubahan konsep yang lebih rinci, lengkap, serta sesuai dengan konsep-konsep metode numerik. Contoh kegiatan refleksi dalam Bab 1 dapat dilihat pada Gambar 6.

Perhatikan lagi soal nomor 1 :

Untuk polinom derajat $>2$, seperti pada soal 1, apakah terdapat rumus aljabar untuk menghitung akar polino

Dari beberapa metode yang Anda ketahui, manakah yang dapat digunakan untuk menentukan akar polinom pada soal nomor 1 ? 


\section{Kelayakan Isi}

Buku ajar ini dilengkapi dengan kompetensi utama, penjelasan karakteristik buku ajar, dan petunjuk penggunaan buku ajar yang dapat digunakan oleh mahasiswa sebagai pedoman dalam belajar secara mandiri. Kompetensi utama berisi penjelasan kemampuan yang dikuasai mahasiswa setelah mengikuti perkuliahan metode numerik selama satu semester. Karakteristik buku ajar menjelaskan cirri khas buku ajar ini yang membuatnya berbeda dengan buku lain. Karakteristik yang dimaksud sesuai dengan pendekatan yang digunakan dalam pengembangan buku ajar ini. Petunjuk penggunaan buku ajar menjelaskan kepada pembaca cara memaksimalkan penggunaan buku sebagai sumber belajar dalam mengkonstruksikan pengetahuan sendiri.

Latihan disajikan pada setiap subbab. Latihan dimaksudkan sebagai pemantapan materi setiap subbab sedangkan latihan ulangan merupakan evaluasi materi satu bab. Soal latihan mewakili setiap subbab sebanyak dua sampai tiga nomor dan ditempatkan setelah penyajian subbab terakhir.

\section{Kebahasaan}

Penggunaan bahasa pada buku ajar yang dikembangkan cukup jelas dan mudah dipahami. Istilah-istilah yang digunakan juga sudah umum dikenal di lingkungan mahasiswa. Beberapa istilah yang digunakan dalam buku ajar adalah galat, angka signifikan, dan iterasi. Istilah-istilah tersebut mudah dilafalkan dan sudah umum digunakan.

\section{Kegrafikan Buku Ajar}

Ukuran buku rancangan awal adalah $21,5 \times 27 \mathrm{~cm}$ (A4) dengan batas tepi kiri $3 \mathrm{~cm}$, kanan $2 \mathrm{~cm}$, atas $2 \mathrm{~cm}$, dan bawah $2,5 \mathrm{~cm}$. Jenis tulisan (font) yang digunakan adalah Cambria Math dan Monotype Corsiva dengan ukuran (size) 12 pt dan tampilan cetak one page per sheet. Layout cover dan bagian isi didesain dengan dominasi warna biru. Menurut Heka (2012) biru yang kuat akan merangsang pemikiran yang jernih dan ringan, biru lembut akan menenangkan pikiran dan konsentrasi bantuan.

\section{Hasil Validasi Prototipe (Prototype)}

Prototipe buku ajar metode numerik berbasis konstruktivisme yang telah dirancang selanjutnya divalidasi oleh pakar.Setelah itu, peneliti berdiskusi dengan validator tentang kevalidan prototipe yang telah dirancang dan meminta saran-saran untuk perbaikan prototipe. Selanjutnya, peneliti memperbaiki prototipe buku ajar metode numerik berbasis konstruktivisme berdasarkan saransaran dari valiator kemudian berdiskusi kembali dengan validator sampai prototipe dinyatakan sudah valid, nama-nama validator dari buku ajar metode numerik berbasis konstruktivisme ini adalah Fauziah, S.PdI, Yusri Wahyuni, M. Pd dan Alfi Yunita, M. Pd.

Data validasi buku ajar diperoleh melalui lembar validasi. Penilaian yang diberikan mencakup empat aspek yaitu penyajian materi, kelayakan isi, kebahasaan, dan aspek kegrafikaan buku ajar.Validasi masing-masing aspek dapat dilihat pada Tabel 6. 
Tabel 6. Data Hasil Validasi Buku Ajar

\begin{tabular}{|c|c|c|c|c|c|c|c|c|}
\hline \multirow{2}{*}{ No } & \multirow{2}{*}{ Aspek yang divalidasi } & \multicolumn{3}{|c|}{ Validator } & \multirow{2}{*}{ Jumlah } & \multirow{2}{*}{$\begin{array}{l}\text { Skor } \\
\text { Maks }\end{array}$} & \multirow{2}{*}{$\%$} & \multirow{2}{*}{ Kategori } \\
\hline & & 1 & 2 & 3 & & & & \\
\hline 1. & $\begin{array}{l}\text { Penyajian materi } \\
\text { berbasis konstruktivisme }\end{array}$ & 51 & 48 & 47 & 147 & 180 & 82 & $\begin{array}{l}\text { Sangat } \\
\text { Valid }\end{array}$ \\
\hline 2. & Kelayakan isi & 23 & 22 & 22 & 67 & 84 & 80 & Valid \\
\hline 3. & Kebahasaan & 31 & 30 & 29 & 90 & 108 & 83 & $\begin{array}{l}\text { Sangat } \\
\text { Valid }\end{array}$ \\
\hline 4. & Kegrafikaan & 28 & 26 & 25 & 79 & 96 & 82 & $\begin{array}{l}\text { Sangat } \\
\text { Valid }\end{array}$ \\
\hline
\end{tabular}

Berdasarkan hasil validasi para ahli dapat dilihat bahwa buku ajar yang dikembangkan sudah valid dari segi kelayakan isi. Dengan demikian, materi, contoh soal, latihan, rangkuman, dan latihan ulangan yang disajikan dengan pendekatan konstruktivisme sudah layak digunakan sebagai buku ajar dalam perkuliahan Metode Numerik.

\section{Hasil Praktikalitas Buku Ajar Metode Numerik Berbasis Konstruktivisme}

Untuk melihat pratikalitas buku ajar ini, dilakukan uji coba terbatas pada kelas A. Data tentang praktis atau tidaknya buku ajar yang yang telah dirancang diperoleh dari hasil angket respon mahasiswa terhadap buku ajar. Berikut ini diuraikan hasil pratikalitas buku ajar berbasis konstruktivisme pada mata kuliah metode numerik.

Berdasarkan hasil pengisian anget oleh mahasiswa, diperoleh skor untuk masing-masing indikator seperti terlihat pada Tabel 7. Hasil analisis skor angket menunjukkan bahwa buku ajar sudah praktis digunakan oleh mahasiswa. Perolehan skor angket masing-masing mahasiswa dapat dilihat pada Tabel 7.

Tabel 7. Hasil Angket Respon Mahasiswa Terhadap Buku Ajar Berbasis Konstruktivisme Pada Mata Kuliah Metode Numerik

\begin{tabular}{|c|c|c|c|c|c|c|c|c|c|c|c|c|c|}
\hline \multirow{2}{*}{ No } & \multirow{2}{*}{ Nama } & \multicolumn{8}{|c|}{ Pernyataan Angket } & \multirow{2}{*}{$\mathrm{Jml}$} & \multirow{2}{*}{$\begin{array}{l}\text { Skor } \\
\text { Maks }\end{array}$} & \multirow{2}{*}{$\%$} & \multirow{2}{*}{ Kategori } \\
\hline & & 1 & 2 & 3 & 4 & 5 & 6 & 7 & 8 & & & & \\
\hline 1 & Melisya & 4 & 3 & 3 & 3 & 4 & 3 & 3 & 3 & 26 & 32 & 81 & $\begin{array}{l}\text { Sangat } \\
\text { Praktis }\end{array}$ \\
\hline 2 & $\begin{array}{l}\text { Devi } \\
\text { Gusdianti }\end{array}$ & 3 & 3 & 2 & 3 & 4 & 3 & 4 & 2 & 24 & 32 & 75 & Praktis \\
\hline 3 & $\begin{array}{l}\text { Lisa F. } \\
\text { Dewita }\end{array}$ & 3 & 3 & 3 & 3 & 3 & 2 & 3 & 2 & 22 & 32 & 69 & Praktis \\
\hline 4 & $\begin{array}{l}\text { Elvia } \\
\text { Rahmi }\end{array}$ & 2 & 2 & 3 & 2 & 3 & 2 & 3 & 2 & 19 & 32 & 59 & $\begin{array}{l}\text { Cukup } \\
\text { Praktis }\end{array}$ \\
\hline 5 & M. Guntur & 3 & 3 & 2 & 2 & 3 & 3 & 3 & 4 & 23 & 32 & 72 & Praktis \\
\hline 6 & $\begin{array}{l}\text { Cicinia } \\
\text { Putri }\end{array}$ & 2 & 3 & 3 & 3 & 3 & 3 & 3 & 3 & 23 & 32 & 72 & Praktis \\
\hline 7 & $\begin{array}{l}\text { Voni Fitri } \\
\text { Yanti }\end{array}$ & 3 & 3 & 3 & 3 & 3 & 3 & 3 & 3 & 24 & 32 & 75 & Praktis \\
\hline 8 & Yuliarnis & 3 & 3 & 3 & 3 & 3 & 4 & 3 & 3 & 25 & 32 & 78 & Praktis \\
\hline
\end{tabular}




\begin{tabular}{|c|c|c|c|c|c|c|c|c|c|c|c|c|c|}
\hline 9 & $\begin{array}{l}\text { Putri } \\
\text { Intannia. N }\end{array}$ & 3 & 2 & 3 & 3 & 3 & 3 & 3 & 3 & 23 & 32 & 72 & Praktis \\
\hline 10 & $\begin{array}{l}\text { Siswi } \\
\text { Diyanti }\end{array}$ & 3 & 3 & 3 & 3 & 4 & 3 & 2 & 3 & 24 & 32 & 75 & $\operatorname{Pr}$ \\
\hline & Jumlah & 29 & 28 & 28 & 28 & 33 & 29 & 30 & 28 & 233 & 320 & 73 & Praktis \\
\hline
\end{tabular}

Hasil analisis skor angket masingmasing mahasiswa menunjukkan bahwa satu dari sepuluh peserta menyatakan buku ajar yang dikembangkan sangat praktis dan yang lainnya menyatakan cukup praktis dan sudah praktis digunakan. Meskipun demikian, prototipe buku ajar. Metode Numerik tetap direvisi berdasarkan temuan-temuan pada saat ujicoba tersebut.

\section{PEMBAHASAN}

\section{Analisis Muka-Belakang}

Berdasarkan hasil wawancara dengan dosen Metode Numerik STAIN Batusangkar diperoleh informasi mengenai keterbatasan buku ajar metode numerik yang mudah dipahami mahasiswa. Beberapa materi dalam buku ajar sudah diberikan pada mata kuliah dasar yang merupakan prasyarat untuk mengambil mata kuliah metode numerik. Dosen juga belum pernah menulis buku ajar metode numerik.

Analisis silabus dilakukan untuk melihat kesesuaian antara materi ajar dengan kompetensi yang harus dicapai mahasiswa. Kompetensi utama mata kuliah metode numerik adalah mahasiswa dapat menjelaskan konsep galat, dapat menggunakan metode numerik untuk menentukan akar persamaan tak linier, menyelesaikan sistem persamaan linier, menginterpolasi titik-titik data, dan dapat menyelesaikan persoalanpersoalan yang terkait dengan metode numerik.

\section{Hasil Perancangan Buku Ajar}

Buku ajar metode numerik berbasis konstruktivisme yang dikembangkan menggunakan pendekatan filosofi konstruktivisme dalam lima langkah sebagaimana yang dikemukakan oleh Nurhadi (2004: 39) yaitu pengaktifan pengetahuan yang sudah ada, pemerolehan pengetahuan baru, pemahaman pengetahuan, menerapkan pengetahuan dan pengalaman yang diperoleh, dan melakukan refleksi.

Selain itu buku ajar dirancang atau dikembangkan sesuai dengan silabus yang ada. Materi dalam buku ajar berbasis konstruktivisme ini dikembangkan terdiri atas 5 bab pembahasan yang diawali dengan bab 1 berisi pendahuluan sebagai pengantar ke metode numerik. Bab 2 membahas tentang sistem bilangan dan galat, bab 3 membahas beberapa metode yang digunakan untuk menentukan akar persamaan tak linier, bab 4 membahas beberapa metode yang digunakan untuk mendapatkan solusi sistem persamaan linier, dan bab 5 membahas metode iterasi. Buku ajar ini dirancang untuk pertemuan satu semester.

\section{Validasi Buku Ajar}

Hasil validasi para ahli menunjukkan bahwa buku ajar yang dikembangkan sudah memuat petunjuk belajar, kompetensi yang akan dicapai, latihan, dan latihan ulangan. Sesuai dengan pendapat Majid (2008: 174) yang menyatakan bahwa sebuah buku ajar mencakup antara lain petunjuk belajar, kompetensi yang akan dicapai, informasi 
pendukung, latihan, petunjuk kerja dapat berupa lembar kerja, dan evaluasi.

Validasi buku ajar dari segi kelayakan isi, diperoleh persentase 80 dengan kategori valid. Hasil validasi tersebut menunjukkan bahwa materi yang terdapat dalam buku ajar sudah sesuai dengan prinsip keilmuan materi tersebut. Materi ajar juga sudah sesuai dengan kompetensi yang diharapkan pada mata kuliah Metode Numerik. Sesuai dengan pendapat Muslich (2010: 115) yang menyatakan bahwa buku ajar yang memiliki kelayakan isi adalah apabila terdapat kesesuaian materi dengan kompetensi utama dan kompetensi pendukung, keakuratan materi, dan materi pendukung pembelajaran.

\section{Raktikalitas Buku Ajar}

Hasil uji praktikalitas menunjukkan bahwa buku ajar yang dikembangkan sudah praktis. Berdasarkan hasil wawancara dengan mahasiswa diperoleh kesimpulan bahwa buku ajar ini sudah menarik dan penyajian materi lebih ringkas sehingga lebih mudah dipahami. Akan tetapi, terdapat beberapa kesalahan dalam pengetikan, sehingga buku ajar yang dikembangkan direvisi kembali sesuai dengan temuan-temuan tersebut.

Hasil uji praktikalitas menunjukkan bahwa buku ajar yang dikembangkan sudah menarik dan dapat digunakan dalam perkuliahan Metode Numerik. Menurut mahasiswa, buku ajar ini manarik karena pembahasan contoh soal disajikan secara lengkap dan jelas sehingga mudah dipahami. Informasi yang disajikan juga membantu mahasiswa dalam memahami materi ajar.

Berdasarkan hasil wawancara dan pengisian angket oleh mahasiswa diperoleh informasi bahwa mahasiswa senang menggunakan buku ajar yang dikembangkan karena mudah dipahami sehingga tidak banyak membutuhkan bimbingan dari dosen. Mahasiswa juga menyatakan bahwa istilah dan kalimat yang digunakan mudah dimengerti.

\section{Keterbatasan Penelitian}

Pengembangan prototipe buku ajar berbasis konstruktivisme mengalami beberapa permasalahan yang menjadi keterbatasan dalam pengembangan ini. Keterbatasan tersebut adalah sebagai berikut:

1. Pengembangan yang dilakukan terbatas pada materi ajar yang sesuai dengan silabus Metode Numerik di STAIN Batusangkar.

2. Tidak semua materi dapat disajikan menggunakan pendekatan konstruktivisme.

3. Implementasi buku ajar hanya dilakukan untuk satu kelas di lingkungan mahasiswa STAIN Batusangkar. Uji lapangan tidak dapat dilakukan karena keterbatasan waktu penelitian.

\section{PENUTUP}

\section{Kesimpulan}

Berdasarkan hasil analisis data dan pembahasan yang telah dilakukan, diperoleh kesimpulan sebagai berikut:

\section{Validitas Buku Ajar Berbasis Konstruktivisme}

Hasil validasi pada tahap tinjauan ahli menunjukkan bahwa buku ajar berbasis konstruktivisme yang dikembangkan untuk mata kuliah metode numerik sudah valid. Penilaian validitas mencakup aspek kelayakan isi, penyajian materi, kebahasaan, dan kegrafikaan. Setiap aspek yang divalidasi sudah 
dikategorikan valid oleh para ahli. Meskipun demikian, prototipe buku ajar tetap mengalami revisi berdasarkan saran-saran dari para ahli dan teman sejawat, serta mahasiswa.

\section{Praktikalitas Buku Ajar Berbasis Konstruktivisme}

Hasil angket yang melibatkan sepuluh mahasiswa STAIN Batusangkar yang telah mengambil mata kuliah Metode Numerik menunjukkan bahwa prototipe buku ajar yang dikembangkan sudah praktis. Penyajian materi pada buku ajar ini mudah dipahami, bahasa yang digunakan jelas dan mudah dimengerti. Buku ajar ini mengurangi ketergantungan mahasiswa terhadap dosen.

\section{Saran}

Berdasarkan hasil pengembangan yang dilakukan, pada bagian ini disajikan beberapa saran yang dapat dijadikan dasar dalam mengambil kebijakan, menggunakan produk, serta untuk melakukan penelitian dan pengembangan lebih lanjut.

\section{DAFTAR RUJUKAN}

Akker, Jan Van Den dan Plom, Tjeerd. 1994. "Educational Development in Developing Countries', dalam Skutsch, Margaret M., Opdam, J. Hans M. and Nordholt, Nico G. Schulte (Eds.), Towards Sustainable Development. Enschede: Technology and Development Group University of Twente.

Fauzan, Ahmad. 2002. Applying Mathematics Education (RME) in
1. Dosen pengampu mata kuliah Metode Numerik dan mahasiswa dapat menggunakan buku ajar berbasis konstruktivisme ini sebagai alternatif sumber belajar dalam kegiatan perkuliahan.

2. Buku ajar ini dikembangkan sesuai dengan silabus Metode Numerik di STAIN Batusangkar. Oleh karena itu, dosen metode numerik dapat mengembangkan buku ajar ini dengan jangkauan materi yang lebih luas sehingga dapat digunakan secara utuh oleh semua perguruan tinggi atau disiplin ilmu yang berbeda.

3. Buku ajar ini juga dapat dikembangkan oleh dosen metode numerik menjadi buku kerja atau modul berbasis konstruktivisme yang dapat digunakan mahasiswa sebagai sarana belajar atau berlatih secara mandiri.

4. Peneliti lain dapat menjadikan buku ajar berbasis konstruktivisme ini sebagai contoh dalam mengembangkan bahan ajar berbasis konstruktivisme pada mata kuliah lain.

Teaching Geometry in Indonesian Primary Schools. Padang.

Majid, Abdul. 2008. Perencanaan Pembelajaran Mengembangkan Standar Kompetensi Guru. Bandung: Remaja Rosdakarya.

Muslich, Masnur. 2010. Text Book Writing. Jogjakarta: Ar-ruz Media.

Nurhadi dkk. 2004. Pembelajaran Kontekstual (Contextual Teaching and Learning/CTL) dan Pene- 
rapannya dalam $K B K$. Malang: Penerbit Universitas Negeri Malang.

Riduwan. 2005. Belajar Mudah Penelitian. Jakarta: Alfabeta.
Suherman, Erman, dkk. 2003. Strategi Pembelajaran Matematika Kontemporer (Common Textbook Edisi Revisi). Jakarta: IMSTEP.

Susila, I Nyoman. 1993. Dasar-dasar Metode Numerik. Depdikbud Dirjen Dikti: PPTKPT. 